УДК 111+141.4:215

Кузнецова К. Ю.

doi:10.32620/gch.2019.3.03

\title{
СЛАБКА ДУМКА («IL PENSIERO DEВОLЕ») TА «СЛАБКА ТЕОЛОГІЯ» ЯК СИМПТОМИ ПОСТМЕТАФІЗИЧНОГО МИСЛЕННЯ
}

Статтю присвячено аналізові формування феномена «ослабленого мислення» як у сфері онтології, так і у сфері теології. Автор пропонує інтерпретувати «слабку думку» в кониепиіï Дж. Ваттімо $\check{u}$ «слабку теологію» Дж. Капуто як окремі прояви постметафізичного мислення, які призводять до встановлення постсекулярної парадигми.

Ключові слова: ослаблене мислення, постметафізика, слабка теологія, постсекулярність.

The article is devoted to the analysis of the formation of the phenomenon of "weakened thinking" both in the field of ontology and in the field of theology. The author proposes to interpret "weak thought" in the concept of J. Vattimo and "weak theology" of J. Caputo as particular manifestations of post-metaphysical thinking leading to the establishment of a post-secular paradigm.

Keywords: weakened thinking, post-metaphysics, weak theology, post-secularity.

Постановка проблеми. Долі метафізики й теології історично тісно пов'язані. Ще від філософії Арістотеля метафізика розглядала себе як prima philosophia, науку про першооснови, найголовнішою $з$ яких виявлявся Бог як першодвигун, гранична підстава й кінцева мета всього сущого. Метафізика закладала підгрунтя для раціональної теології в Середні віки й зберігала філософського Бога як causa sui в новоєвропейській філософії. Цей зв'язок настільки тісний, що М. Гайдеггер говорить про внутрішню подвійність метафізики: «Свропейська метафізика з часу ії появи у греків, і без будь-якого зв'язку з цими іменами, є онтологія і теологія» [6]. Він мислить цю подвійність із внутрішньої подвійності (яка не скасовує його єдності) визначення метафізики, що одночасно постає як metaphysica generalis, наука про суще як суще (тобто онтологія) i metaphysica specialis, наука про вище суще (тобто теологія).

У кінці XX ст. запитування про Бога стало настільки нагальною проблемою, що змусило деяких дослідників говорити про «теологічний поворот» у філософії. Критика метафізики, ставлячи питання про иї подолання, призводила до радикальних трансформацій стосовно філософської методології, покликаних здійснити революційні зміни в онтотеологічній будові філософії. Оскільки теологія й онтологія виявляються тісно взаємопов'язаними, спроби подолання метафізики не можуть не впливати й на раціональну теологію, підриваючи можливість ії філософських підстав, що, утім, зовсім не сприймалося в теології однозначно як проблема, бо лише ставило під питання раціональні підстави теологіï i iii метафізичну будову, тим самим повертаючи їй іiі природну безосновність. Тому створюється парадоксальна ситуація, коли, як зауважив Гайдеггер, «безбожне мислення, вимушене відмовитися від 
філософського бога, бога як causa sui, мабуть, ближче Богу божественному. I значить це тільки те, що тут Йому вільніше, ніж здатна допустити онтотеологіка» [6, с. 57-58].

У центрі уваги виявляється питання: як можливо повернути Бога в мислення й «привести його до мови» «після проходження через сучасність», що передбачає осмислення не тільки кризи метафізичного мислення, а й кризи «секулярного розуму». В останні два десятиліття тональність богословських і філософських текстів сконцентрувалася навколо слова «після» - після метафізики, після Бога тощо. Основною стала ідея метафізики після Бога, Бога після метафізики, проект релігії без релігії.

Сучасну філософію, яка шукає відповіді на це питання, багато дослідників характеризують як постметафізичну, причому не завжди вживання терміна «постметафізичне мислення» відповідає трактуванню Ю. Габермаса [9] або якомусь іншому, залишаючись тим самим розмитим, нез'ясованим й усереднено зрозумілим. У той час як існує погляд, згідно з яким неможливе або проблематичне саме існування філософського знання поза метафізикою й усі неметафізичні способи філософування не визнаються повноцінною філософською думкою, Габермас виразно говорить про кінець метафізичної філософії. Дві ідеї - розуму як джерела світоконституювальних ідей та історії як середовища, у якому розум здійснює свій синтез, -революціонізували основні концепти метафізики й призвели до появи питань, які й породили постметафізичне мислення.

Сутність сучасного стану модернізму виражає не постмодернізм, а саме постметафізичне мислення, більш вдало вписане в повсякденну практику наукової й соціальної комунікації. Тому класична метафізика змінюється не метафізикою модерністською й подальшими постмодерністськими інноваціями, а постметафізичним мисленням, що повертає нас до життєвого світу і яке характеризує сучасний стан філософії з погляду іiі аксіологічної (а не онтологічно-метафізичної) ваги для наукового пізнання.

Як найбільш загальні характерні риси постметафізичного мислення визначаємо такі: відмову від можливості побудови єдиної концептуальної системи (що протиставляється метафізиці, орієнтованій на прославлення початку), настанову на зв'язок сенсу 3 інтерпретативними практиками, деконструкцію бінарних опозицій, примат сингулярного над загальним. Ці риси говорять скоріше не про «подолання метафізики» в тому розумінні, як про це йдеться в позитивізмі, це не «відкидання» або ліквідація метафізичного як «застарілого», іррелевантного, ненаукового. Швидше йдеться про те, що метафізичне - це спроба звести різноманіття до єдності, а відмінність - до тотожності, а постметафізичне мислення - це спроба уникнути цих тенденцій. Зазначимо, що поява постметафізичного мислення, на нашу думку, багато в чому пов'язана з ідеями самообмеження розуму й «смерті Бога», які утворилися у філософських системах І. Канта і Ф. Ніцше відповідно. Обмеження претензій як розуму й супутніх йому секулярних практик (тут ми маємо на увазі в тому числі й науку), так і релігії сприяло створенню умов, у яких жодна світопояснювальна практика не має онтологічної переваги над іншими.

Аналіз останніх досліджень і публікацій. У постметафізичному ключі 
намагаються вибудувати феноменологічний підхід у теології Ж.-Л.Маріон і Е. Левінас, деконструювати релігійний дискурс - Ж. Дерріда й Дж. Капуто, створити герменевтично-комунікативний дискурс у трактуванні релігії -Дж. Ваттімо, С. Забала, Р. Рорті та Ю. Габермас.

У виявленні основних рис постметафізичної онтології, хоча й не завжди акцентуючи увагу на ii постметафізичному характері, допомагають дослідження трансформації сфери онтології після завершення філософії суб'єкта А. Бадью, Дж. Ваттімо, М. Бланшо, В. Декомба, М. Анрі, Е. Левінаса, Ж.-Ф. Ліотара, С. Забали.

Зміна ролі й місця релігії в епоху глобалізації, в умовах секуляризації та десекуляризації, сучасні тенденції у сфері релігії проаналізовано в роботах П. Бергера, С. Бурьянова, О. Кирлєжева, В. Новіка, Ю. Габермаса, С. Хантінгтона, С. Філатова, Ф. Фукуями, М. Епштейна, М. Мілбанка, Д. Узланера. Серед українських дослідників секуляризації та постсекулярності можна відзначити таких, як О. Білокобильський, О. Богданова, С. Гераськов, В. Гуржи, К. Гуржи, А. Долгочуб, Т. Срошенко, Р. Халіков, Ф. Шандор та ін.

Незважаючи на різноманіття літератури 3 дотичних тем, залишається нерозв'язаним питання про прояви постметафізичного мислення в сучасних філософсько-теологічних концепціях i зв'язок постметафізики 3 постсекулярним суспільством, що зараз формується.

Мета статті - схарактеризувати «слабку думку» Дж. Ваттімо й «слабку теологію» Дж. Капуто як передумови формування постсекулярного стану співвідношення між філософією й релігією.

Виклад основного матеріалу. Подану в працях Фрідріха Ніцше й Мартіна Гайдеггера нігілістичну лінію в критиці метафізики продовжує Джанні Ваттімо, який пропонує філософський підхід, відомий як «ilpensierodebole» - «слабка думка». Починаючи 3 Ніцше й далі знаходячи свій розвиток у постмодерністській думці ХХ ст., сучасна філософія «ховає» паскалівського Бога філософів, який був метафізичною основою минулого світу. «Смерть» такого Бога надає можливість для відродження «нової життєвої релігії» [1, с. 22]. На думку Ваттімо, розпалися поняття загального унітарного сенсу історії, абсолютної істини, та їх ексгумація не віщує нічого втішного.

Специфіка герменевтики, яку практикують Капуто й Ваттімо, безпосередньо пов'язана 3 ключовим моментом у побудовах обох мислителів - концепцією мислення, що послабляє. Для Ваттімо, слабка думка (pensiero debole) належить до поступового ослаблення буття, яке перетворило сучасну філософію від іiі «одержимості» метафізикою істини до локальної раціональності й усвідомлення герменевтичної природи будь-якої істини. Можна виділити два аспекти процесу ослаблення думки. Перший процес - ослаблення буття - від об'єктивної метафізичної структури до інтерпретації («події» в гайдеггерівському розумінні). Він описаний ніцшеанською мовою нігілізму, що означає історичний процес, у межах якого об’єктивістські претензї метафізики, абсолютні підстави стали недостовірними (або звелися до «ніщо»), ослабли, і їх замінили «перспективи» або інтерпретативні схеми.

Другий процес - ослаблення Бога у світі, описаний мовою апостола Павла в 
термінах применшення - kenosis, який є парадигматичним виразом християнської доктрини втілення, народження й смерті Iсyca. Kenosis - не одноразова подія, що відбулася в житті і смерті Ісуса, але тривала історія або традиція, ініційована цією подією. Цей процес Ваттімо називає «секуляризацією», що означає не відмову від Бога, але свого роду «транскрипцію» Бога в час та історію (saeculum). Тим самим нігілізм i kenosis виявляються паралельними процесами. Нігілізм - спустошення буття в інтерпретативну структуру; kenosis - сходження до ніщо Бога як трансцендентного божества. Kenosis розуміють як транскрипцію, переклад або передання Бога у світ, засіб установити Царство Боже на землі. Це ідея, політичний корелят якої - неавторитарна демократія, а епістемологічний корелят - гадамерове розуміння діалогу.

Саме «завершення метафізики та смерть морального Бога зруйнувала самі засновки філософського атеїзму», що призвело до небаченної релігійності [1, с. 2425] й актуалізації паскалівського парі, у якому йдеться, що в будь-якому разі (навіть якщо Бога нема) вірити в нього вигідніше, ніж не вірити [91, с. 27]. Ваттімо трактує ніцшеанські слова про смерть Бога в розумінні вказівки на відсутність останньої підстави, що звільняє релігію від метафізики: «Саме тому що Бог - остання підстава, тобто абсолютна метафізична структура реальності, - віднині втрачений, віра в Бога знову стає можливою» [1, с. 10].

За Ваттімо, філософія традиційно визначалася «сильними» концепціями буття й мислення. Ці концепції повинні були бути всеохопними й обов'язковими в нормативному плані, тобто повинні були бути сильними й за своїм обсягом, і за теоретичними вимогами. Примат принципів, а також опора на об'єднувальні й узагальнювальні категорії свідчили, як уважає Ваттімо, що традиційній метафізиці був притаманний момент насильства.

Дебольне мислення символізує (або відкриває для себе) кінець стабільної структури буття й кінець епохи філософського модерну від Декарта до Ніцше 3 їі домінантними ідеями просвітництва розуму й прориву до граничних підстав. За визначенням Ваттімо, перехід від модерну до постмодерну, до «слабкої думки» $\epsilon$ перехід від сильних стабільних структур до слабких структур, від сильних єдностей до слабких множин, від панування - до свободи, від авторитарної влади - до демократії [2, с. 131].

Парадокс у тому, що ослаблене онтологічне мислення не тільки слугує постметафізичному перегляду авторитарно-метафізичних підстав теології, але й послабляє не менш метафізичні доводи атеїзму й релігійної критики, створюючи перспективу для постсекулярного мислення. Для Ваттімо атеїзм - зворотний бік теїзму, і обидва вони далекі від розуміння справжнього характеру віри, оскільки зберігають абсолютистські домагання наукового позитивізму або трансцендентного авторитету. Атеїзм, так само як і релігійний фундаменталізм, виявляються проявом певної відмови від прочитання, формою «метафізичного насилля», або, що одне й те саме, «історичними неврозами». Завершення метафізики, котра $\epsilon$ вірою в обгрунтований, стабільний, необхідний, об'єктивно збагненний порядок буття, супроводжувалося теоретичною й соціальною смертю Бога, Бога філософів, але 
одночасно й відродженням різноманітних форм сакрального. Завершення метафізики є всього лише ослабленням буття, відсутністю єдиної однозначної інтерпретації буття, що поступається нескінченній різноманітності інтерпретацій, у яких ми існуємо.

Ослаблене мислення звернене до такого виду герменевтичного досвіду, до таких його нових онтологічних умов, які можуть бути охарактеризовані тільки нігілістично, як радикальний розрив із буттям - тобто 3 будь-якою гарантованістю, «визначеністю», даністю: буттям, яке мислиться метафізично - як «субстанції», «апріорність», «очевидності розуму», «граничні підстави», - або розуміється як історична даність, що характеризується рисами «сильної реальності» - «держава», «церква», «нація», «Захід».

Ваттімо заперечує уявлення про реальність як про «масивну, стабільну, вічну структуру». Він радикальним чином історизує буття й наділяє його характером подієвості. «Буття» постає не інакше як подія, воно трапляється як істориколінгвістичні горизонти, у межах яких суще стає доступним для нас. Для цілей епохи Постмодерну неправильно наділяти буття «сильними» властивостями (єдністю, абсолютністю тощо), як це робила метафізична традиція. Більш правомірними постають «слабкі» й «постмодерні» властивості, такі як плюральность, темпоральність і кінцевість.

За словами Ваттімо, «(тільки) завдяки розпаду метафізичних метанаративів філософія знову відкрила для себе переконливість релігії, отже, змогла наблизитися до релігійної потреби у загальній свідомості, незалежно від звичної просвітницької критики» [10, с. 84]. Інформаційна революція, становлення постнекласичної науки, постмодерністське мистецтво, культурний плюралізм, зміна в стилістиці повсякденного життя західного світу й низка інших факторів підготували народження феномена, позначеного Дж. Ваттімо як «послаблення відчуття реальності». Його результатом, насправді, стало поширення постсекулярної свідомості, яку рівною мірою поділяють як прихильники постмодерністської філософії, так і їі опоненти.

С. Забала вважає, що «метафізична традиція виходила 3 того, що існує щось нелюдське, з чим люди повинні намагатися жити» [5, с. 93]. За аналогією з терміном «ослаблене мислення», уведеним Дж Ваттімо для характеристики сучасної постметафізичної філософії, тут ідеться про «слабкого Бога» на противагу онтологічному. Це ослаблене християнство переміщує Бога у сферу комунікації та інтерпретації, відмовляючись від метафор онтологічної висоти й глибини. Таку позицію можна було б назвати своєрідним інтерпретаційним пантеїзмом. Метафізика для Ваттімо - це перш за все «відірваність сутностей від повсякденного життя» [5, с. 101], і саме їі він і пропонує подолати.

У постметафізичному мисленні неможлива «сильна віра в Бога, подібно до того як онтологічне мислення взагалі стає ослабленим, віра грунтується не на доказі буття вищої істоти, а на довірі до Біблії і любові, яка може не бачити речі такими, якими «вони є в реальності» [4, с. 106].

У позитивному плані «слабке мислення» й онтологія Ваттімо прагнуть бути герменевтичними та нігілістськими в дусі гайдеггеріанської онтології. Філософія 
Ваттімо прагне врятувати онтологічний дискурс, не зробивши його при цьому метафізичним у традиційному розумінні. Якщо говорити більш конкретно, ця філософія визнає світ символічних форм, світ дій, визнає різні практики, сприймаючи їх як різні мови розуму.

На думку Ваттімо, постметафізична філософія займається осмисленням i критикою багатогранних феноменів релігійного повороту в культурі й тим самим ставить цю культуру «під питання» та свідчить про «ослаблення буття». Для того щоб «повернення релігії» 3 секулярного погляду було «законним», воно повинно проходити через «смерть Бога» й, отже, бути «слабким». Релігія й секуляризація в такій «слабкій» формі, за Ваттімо, збігаються.

У постметафізичному мисленні неможлива «сильна» віра в Бога: подібно до того, як онтологічне мислення взагалі стає ослабленим, віра грунтується не на доказі буття вищої істоти, а на довірі до Біблії і любові, яка може не бачити речей такими, якими «вони $є$ в реальності». Однак, ослаблене онтологічне мислення не тільки слугує для постметафізичного перегляду авторитарно-метафізичних підстав теології, а й послаблює не менше метафізичні аргументи атеїзму й релігійної критики, створюючи перспективу для постсекулярного мислення: «Завершення метафізики i смерть морального Бога зруйнувало самі підстави філософського атеїзму» [1, с. 10].

Капуто постає як постметафізичний мислитель, підходячи до метафізики в першу чергу як до системи владних відносин і намагаючись не боротися 3 нею, а переставити акценти, щоб показати інший бік сили, підриваючи таким чином імперські претензії «сильного» мислення не тільки в метафізиці, а й у пов’язаній із нею теології.

Радикалізуючи гайдеггерівський проект подолання метафізики присутності, Капуто говорить про теологію події як про слабку теологію, яка з'являється у відповідь на поклик, що виходить від події, збереженої в імені Бога [8]. Для сильного богослов'я, утвореного в результаті взаємодії раннього християнства 3 грецькою філософією, притаманний класичний філософський підхід, що полягає у формулюванні системи пропозиціональних тверджень. Його логос виражається в предикативних твердженнях, за допомогою яких Бог отримує визначення в образі носія комплексу певних концептуальних властивостей, відомих у класичній теології як атрибути Бога. Зібрані разом за допомогою засобів класичної логіки, ці атрибути, за задумом, повинні створити цілісну картину існування й природи Бога.

У сильній теології Бог постає як всемогутній і всеприсутній правитель Всесвіту, теологія події прагне показати, що слабка сила Бога осідає нижче в прихованих порожнинах буття. Слабка теологія не вважає Бога ні вищим сущим, ні буттям самим по собі, ні причиною або підставою буття. Звільняючи ім'я Бога $з$ порядку буття, вона звільняє подію, звільняє провокативну й призовну силу цього імені, яке розсіюється у всіх напрямках, не обмежуючи цю силу ім'ям присутнього сущого. Тут Бог не розглядається ні як вище суще, чиє існування може бути доведене або спростоване, ні як горизонт буття, Бог узагалі виведений 3 теологічної схеми, яка циркулює між буттям і сущим. Подібне виведення імені Бога 3 онтологічного порядку зближує підхід слабкої теології з гуссерлівським епохе, у слабкій теології утримуються від 
суджень щодо того, існує де-небудь чи ні суще, іменоване Богом.

Замість усемогутнього Бога як arche космосу, заявленого в метафізичній теології, Капуто розглядає Бога як слабку силу, яка надає форму невизначеним елементам, скоріше як заклик, ніж першопричину. Відповідаючи на запитання, спровоковане гайдеггерівською й деррідеанською критикою метафізичного мислення: «Хто або що приходить після Бога онтотеології?», - Джон Капуто дає цілком деконструктивістську відповідь: це Бог письма, точніше, Писання. На відміну від раціональної теології, більш зосередженої на Слові Бога, Капуто стурбований ім'ям (іменами) Бога. Для Капуто ім’я Бога є «позначення або інтерпретація, а не субстанція» [7].

Перебудована подібним чином постметафізична теологія не може бути догматичною, оскільки будь-які догмати - це встановлення влади. У цьому Капуто солідаризується 3 Ваттімо, для якого «неметафізична релігійність також $\epsilon$ немісіонерською». На місце войовничих метафізичних доктрин у теології повинна прийти «слабка теологія», неконфесійна, недогматична, плюралістична та толерантна. Капуто розділяє два варіанти віри: доктринальні вірування «всередині нашої голови» (beliefs) і глибинну віру серця (faith). Якщо партикулярні вірування-beliefs пов’язані 3 відстоюванням позицій, які можуть помінятися, то глибинна вipa-faith - це віра безпосередньо в життя. Однак будь-яка опозиція підлягає деконструюванню, тому ці дві віри хоча протистоять одна одній, виявляються пов'язаними разом, проникаючи й підтримуючи одна одну.

Критика логоцентризму, спрямована на деконструкцію метафізики в філософському мисленні, на перший погляд зовсім не зачіпає релігійні побудови, тому що, на відміну від філософії, теологія зовсім не зобов'язана бути вільним раціональним мисленням. Цілком свідомо, явно й навмисно богослов'я може й повинно бути логоцентричним, тобто ієрархічно структурованим мисленням із центральним поняттям, що пригнічує маргінальні, невбудовані в систему філософеми. Із цієї позиції ціннісні настанови постмодерністського мислення є несумісними 3 ортодоксальними, і для віруючої людини немає проблеми вибору між ними. Однак питання полягає зовсім не в тому, що шляхи теології повинні нарешті розійтися 3 філософією, каменем спотикання для чого має стати питання про метафізику. Деконструкція метафізики зовсім не означає «подолання» або остаточне завершення метафізики, відмову від неї. Та й розірвати зв'язок із філософією для теології в принципі неможливо. Деконструкція $\epsilon$, крім іншого, спробою промислити постметафізичні стратегії мислення в теології, тому, як заявляє Дерріда, «ті, хто хотів би розглядати деконструкцію як символ нігілізму епох модернізму i/aбо постмодерну, повинні, насправді, визнати в ній останнє свідоцтво - якщо не сказати мучеництво - віри в умовах fin de siècle»[3, c. 346].

Висновки i перспективи подальших досліджень. Таким чином, епістемологічні міркування сучасної філософії щодо релігії можуть бути сформульовані в двох версіях: слабкій і сильній. Згідно зі слабкою версією, релігійні змісти є потенційним резервуаром цінних змістів, ідей, аргументів, які можуть бути використані в публічному просторі. Однак їх епістемологічна неповноцінність, яка формулюється, зокрема, їх партикуляризмом, вимагає постійної процедури перекладу 
цих змістів із приватної мови конкретних релігійних «інтерпретувальних спільнот» на загальновагому універсальну секулярну мову. У своїй більш сильній версії це міркування призводить до релятивізації наукового секулярного дискурсу, його перетворення в одну 3 можливих мов, укорінених у конкретній інтелектуальній традиції. Ця інтелектуальна традиція - не краща й не гірша за інші інтелектуальні традиції, однією з яких $є$ традиція християнської рефлексії. Якщо в природничонаукових суперечках ця теза навряд чи витримує критику, то як тільки ця суперечка виводиться в публічну сферу й починає зачіпати ключові морально-практичні питання, рівність традицій дає про себе знати.

Відбувається зближення теології та філософії, які відтепер не протиставляються одна одній, але зустрічаються в якомусь новому просторі, який ми називаємо постсекулярною філософією.

\section{Література:}

1. Ваттимо Дж. После христианства. М. : Три квадрата, 2007. 172 с.

2. Ваттимо Дж. Техника и существование. М. : Канон-плюс, 2013. 207 с.

3. Деррида Ж. Как избежать разговора: денегации. Деконструкция: тексты и интерпретация / Сост. Е. Гурко. Минск : Издательский центр «ЭКОНОМПРЕСС», 2001. 320 с.

4. Малкина С. М. Постметафизическая теология: герменевтико-прагматическая версия. Мир человека: нормативное измерение. 4: Гуманитарное знание : сборник трудов международной научной конференции (Саратов, 4-6 июня 2015 г.). Саратов : ООО Издательство «КУБиК», 2015. С. 102-107.

5. Рорти Р., Ваттимо Дж., Забала С. Каково будущее религии после метафизики? Логос. 2008. № 4. С. 93-110.

6. Хайдеггер М. Онто-теологическое строение метафизики. Тождество и различие. М. : «Логос», 1997. С. 29-60. URL : http://filosof.historic.ru/books/item/f00/s00/z0000294/ (дата звернення : 29.06.2019).

7. Caputo J. D. Spectral Hermeneutics / Caputo J.D., Vattimo G. After the Death of God. N.Y.: Columbia University Press, 2007. 216 p.

8. Caputo J. D. The insistence of God: a theology of perhaps. Bloomington : Indiana University Press, 2013. $320 \mathrm{p}$.

9. Habermas J. Postmetaphysical thinking: Philosophical essays. Cambridge ; L., 1992. 241 p.

10. Vattimo G. The Trace of the Trace. Religion (Cultural Memory in the Present). Stanford, Calif : Stanford University Press, 1998. Pp.79-94.

\section{References:}

1. Vattimo, D. (2007), Posle hristianstva [After Christianity], Tri kvadrata, Moscow. (in Rus.). (in Rus.).

2. Vattimo, D. (2013), Tehnika i sushhestvovanie [Technique and existence], Kanon-pljus, Moscow.

3. Derrida, Zh. (2001), "Kak izbezhat' razgovora: denegacii" [How to Avoid Speaking: Denials]. Dekonstrukcija: teksty i interpretacija [Deconstruction: texts and interpretation], Jekonompress, Minsk, pp. 251-316.

4. Malkina, S. M. (2015), "Postmetafizicheskaja teologija: germenevtiko-pragmaticheskaja versija" [Post-metaphysical theology: hermeneutic-pragmatic version]. Mir cheloveka: normativnoe izmerenie [Human world: normative dimension], vol. 4, pp. 102-107.

5. Rorti R., Vattimo D. and Zabala S. (2008), Kakovo budushhee religii posle metafiziki? [What is the future of religion after metaphysics?], Logos, No. 4, pp. 93-110. 
6. Hajdegger, M. (1997), "Onto-teologicheskoe stroenie metafiziki” [Onto-theological structure of metaphysics], Tozhdestvo i razlichie [Identity and difference], «Logos», Moscow, pp. 29-60.

7. Caputo J. D. (2007). Spectral Hermeneutics. After the Death of God, Columbia University Press, N.Y.

8. Caputo, J. D. (2013), The insistence of God: a theology of perhaps, Indiana University Press, Bloomington. London.

9. Habermas, J. (1992), Postmetaphysical thinking: Philosophical essays, The MIT Press, Cambridge,

10. Vattimo G. (1998), The Trace of the Trace. Religion (Cultural Memory in the Present), Stanford University Press, Stanford, Calif, pp.79-94.

\section{Kateryna Kuznetsova}

\section{WEAK THOUGHT ("IL PENSIERO DEBOLE") AND “WEAK THEOLOGY" AS SYMPTOMS OF POSTMETAPHYSICAL THINKING}

The growing political influence of religious communities and beliefs, the growing presence of religious discourse in public sphere require a rethinking of the role of religion in modern society. A number of mutual accusations in a metaphysical way of thinking leads to the fact that the whole philosophy of the XX century turns out to be a philosophy thinking in a "post" situation. Formation of the "post" states is entirely explained in the field of social philosophy, which tries to "keep pace with time", but the intrigue lies in the fact that in the first place these transformations touched the most fundamental and "eternal" field of philosophy ontology. After Heidegger's thesis on the ontoteological structure of metaphysics, the discourse at the end of metaphysics and post-metaphysical philosophical thinking not only inevitably affect the problem of theology, but connect the problems of updating philosophy and theology in the XX-XXI centuries as well.

Along with the decline of metaphysics as a system philosophy that is able to propose a coherent, unified, well-grounded picture of immutable structures of existence, the very possibility of philosophical refutation of the existence of God is exhausted. It defends the possibility of religious experience. The pluralism of the post-metaphysical era eliminates the possibility of any theoretical distinction between metaphorical and non-metaphorical languages. On the other hand, the famous statement by F. Nietzsche about the death of God, which is inscribed in the context of the critique of metaphysics, symbolically means the final decay of the religious way of thinking and the flowering of secularization, which means the rejection of appeals to other levels of being, except in the focus of today and everyday life.

The specificity of hermeneutics, which is practiced by Caputo and Vattimo, is directly related to the key moment in the constructs of both thinkers - the concept of weakening thinking. For Vattimo, a weak thought (pensiero debole) refers to the gradual weakening of being, which turned the modern philosophy from its "obsession" with the metaphysics of truth to the local rationality and awareness of the hermeneutic nature of any truth. There are two aspects of weakening opinion. The first process - the weakening of being - from the objective metaphysical structure to the interpretation ("events" in the Heideggerian sense). It is described in the Nietzschean language of nihilism, which means the historical process, within which objectivistic claims of metaphysics, absolute grounds have become false (or reduced to "nothing"), weakened, and replaced by "prospects" or interpretative schemes. 
The second process is the weakening of God in the world, described in the language of the apostle Paul in terms of subtlety - kenosis, which is a paradigmatic expression of the Christian doctrine of the incarnation, birth and death of Jesus. Kenosis is not a one-time event that took place in the life and death of Jesus, but the continuing history or tradition initiated by this event. This process is called "secularization" by Vattimo, which doesn't mean a rejection of God, but a kind of "transcription" of God in time and history (saeculum). Thus, nihilism and kenosis are parallel processes. Nihilism is the devastation of being in an interpretative structure; kenosis is the ascension to nothing of God as transcendental deity. Kenosis is understood as transcription, translation or transfer of God into the world, a means to establish the Kingdom of God on earth. This idea, the political correlation of which is non-authoritarian democracy, and the epistemological correlate, is a Gadamer's understanding of dialogue.

On the positive side Vattimo's "weak thinking" and the ontology, seek to be hermeneutical and nihilistic in the spirit of the Heideggerian ontology. Vattimo's philosophy seeks to save ontological discourse without making it metaphysical in the traditional sense. To speak more specifically, this philosophy recognizes the world of symbolic forms, the world of action, recognizes different practices, perceiving them as different languages of the mind.

Describing postmodernity as a "more enlightened Enlightenment", where there is no longer a dream about pure objectivity, Caputo emphasizes that the modern rebirth of religion returns its original meaning - faith, not less form of knowledge. Therefore, religious truth is characterized as truth without knowledge, and modern religiousness as "religion without religion".

By reducing the ontological and theological thought there is a convergence of theology and philosophy, which now do not contradict each other, but are found in some new space, which we call post-secular philosophy.

Keywords: weakened thinking, post-metaphysics, weak theology, post-secularity.

\section{Катерина Кузнецова}

\section{СЛАБКА ДУМКА («IL PENSIERO DEВOLE») I «СЛАБКА ТЕОЛОГІЯ» ЯК СИМПТОМИ ПОСТМЕТАФІЗИЧНОГО МИСЛЕННЯ}

Зросталий політичний вплив релігійних громад і вірувань, зростала присутність релігійного дискурсу в публічній сфері вимагають переосмислення ролі релігії в сучасному суспільстві. Ряд взаємних звинувачень у метафізичному способі мислення призводить до того, що вся філософія ХХ ст. у певному розумінні виявляється філософським мисленням у ситуації «пост-». Формування станів «пост-» цілком пояснюється у сфері соціальної філософії, яка намагається «йти в ногу з часом», але інтрига полягає в тому, що в першу чергу ці перетворення торкнулися найбільш фундаментальної і, здавалося б, «вічної» сфери філософії - онтології. Після тези Гайдеґера про онтотеологічну структуру метафізики, дискурс на кінець метафізики й постметафізичне філософське мислення не тільки неминуче впливає на проблему теології, але й безпосередньо пов'язує проблеми оновлення філософії і теології у XXXXI ст.

Одночасно із занепадом метафізики як системної філософії, здатної запропонувати цілісну, єдину, обгрунтовану картину незмінних структур існування, вичерпана сама 
можливість філософського спростування існування Бога. Це захищає можливість релігійного досвіду. Плюралізм постметафізичної ери виключає можливість будь-якої теоретичної відмінності між метафоричними й неметафоричними мовами. Із другого боку, знаменита заява Ф. Ніцше про смерть Бога, уписана в контекст критики метафізики, символічно означає остаточне розкладання релігійного способу мислення й розквіт секуляризації, що означає відмову від звернень до інших рівнів буття, окрім сьогоднішнього й повсякденного життя.

Німецький дослідник постмодернізму Одо Маквард уважає проголошення смерті Бога знаком нашого часу. Подібно як грецька цивілізація на певному етапі захопилася скептицизмом, а Середньовіччя відкрило для себе номіналізм, наша епоха захоплена «слабкою думкою», у межах якої немає місця для величних тез про Бога, правду, сенс історії, гідність людини тощо. Ці тези трактують як певні міфи, що вичерпали свої культуротворчі функції. Їхнє місце заступають малі наративи «слабкої думки», які заторкують лише окремі неістотні сфери людського існування.

Iз позитивного боку «слабке мислення» й онтологія Ваттімо прагнуть бути герменевтичними й нігілістичними в дусі гайдегерівської онтології. Філософія Ваттімо прагне зберегти онтологічний дискурс, не роблячи його метафізичним у традиційному розумінні. Говорячи конкретніше, ця філософія визнає світ символічних форм, світ дії, визнає різні практики, сприймаючи їх як різні мови розуму.

Описуючи постмодернізм як «більш просвітлене Просвітництво», де більше не існує мрії про чисту об’єктивність, Капуто підкреслює, що сучасне відродження релігії повертає їй первісний зміст - віру, а не менш знання. Тому релігійна істина характеризується як істина без знання, а сучасна релігійність - як «релігія без релігії».

Завдяки ослабленню онтологічної й богословської думки відбувається зближення теології і філософії, які тепер не суперечать одна одній, а зустрічаються в якомусь новому просторі, який ми називаємо постсекулярною філософією.

Ключові слова: ослаблене мислення, постметафізика, слабка теологія, постсекулярність.

Kuznetsova Kateryna - Lecturer of the Department of Theoretical and Practical Philosophy named after Professor J. B. Schad, School of Philosophy, V. N. Karazin Kharkiv National University.

Кузнецова Катерина - викладач кафедри теоретичної і практичної філософії імені професора Й. Б. Шада філософського факультету Харківського національного університету імені В. Н. Каразіна.

e-mail: dolgopol.catherine@gmail.com

Надійшла до редакції 22.04.2019. Розглянута на редколегії 27.08.2019.

\section{Рецензенти:}

Доктор філософських наук, професор кафедри філософії Національного аерокосмічного університету ім. М. С. Жуковського «ХАІ» Кузнецов А. Ю.

Кандидат філософських наук, завідувач кафедри документознавства та української мови гуманітарного факультету Національного аерокосмічного університету ім. М. Є. Жукуовського «XАI» Прилуцька А. Є. 